\section{Velikovsky defended}

SIR - Yet another book and book review (Nature 25 April, p.692) on Velikovsky! Many people who have been warned off reading him by earlier writings must wonder how long this will go on and why. Are there really people who read Velikovsky, and if so, why would anybody with sense read so poorly recommended an author? Perhaps my experience will provide some indication.

I never dreamed of reading Velikovsky for ten years after his first book, Worlds in Collision, because the publisher's illconsidered advertisement suggested it was written in support of religious literalism, and scientific critics, rather rabid sounding but presumably competent, spoke unfavourably of him. I only became curious and started to read him when, as a commuter in need of reading matter, I saw some literary figure quoted to the effect that Velikovsky was much a better writer than his critics. He does indeed read well. His sentences flow, one paragraph leads into another and there is never a moment of boredom at which to break off. The catastrophes are vividly described, the reasons advanced for believing in them interesting.

The reasons may, of course, be quite wrong, but that uncertainty is part of the charm of such reading. If a Velikovskyan catastrophe seems an implausible explanation of the sudden death of the Siberian mammoths, one is at least impelled to wonder again what kind of catastrophe it was. If Velikovsky, in spite of some mildly favourable remarks by Einstein, seems unlikely to have discovered electrostatic forces neglected by the astronomers, one becomes curious to know the basic physics, the degree of unanimity of the astronomers, earlier theories (if any) of electrostatics in astronomy, whether, as Velikovsky claims, the recent space probes tell something relevant and whether Einstein had a habit of encouraging eccentrics.

Critics have made much of Velikovsky's alleged appeal to the ignorant and also to his supposed religious motivation, something never documented and which I do not find in his books. He continues to be read because he appeals to the intellect and the imagination, and to a hunger for good writing.

$53 \mathrm{~W}$. Beaumont Road,

Columbus, Ohio 43214, USA

\section{Arms talks}

SIR - Your leading article (Nature 21 March, p.205) about the Geneva arms talks is a sensible argument about strategies for the negotiations. You recommend that expectations not be built too high too soon, and I concur wholeheartedly. These are the most difficult negotiations we have entered into with the Soviets, because there are three subgroups on space and defence; intermediate-range nuclear weapons and strategic weapons.

These negotiations will take years. Interim agreements along the way would be reasonable objectives. Both sides must be willing to pursue confidence-building measures designed to lessen tensions, and to give hope to people living under each flag that a period of lessening fear is possible, even probable. Improving the atmosphere for negotiations by ratifying the two unratified testing treaties might also be helpful. And trying to understand the issues from the other fellow's side of the table is sound advice indeed. To do that, we need to comprehend more about the other fellow, and even more than that, we need to know the fears, hopes and dreams of his countrymen.

TED STEVEnS

US Senator

United States Senate, Republican, Alaska

Committee on Appropriations, Washington, DC 20510, USA

\section{Cuts in wrong place}

SIR - I have recently been following the debate over the Natural Environment Research Council (NERC) corporate plan in your pages. I have been interested in the work of some of the NERC institutes, particularly that undertaken by the Institute of Marine Environmental Research (IMER), the Freshwater Biology Association (FBA) and the Institute of Terrestrial Ecology (ITE), all of which are represented in the area in which I am presently but temporarily in residence.

I teach, and have taught, environmental science subjects in colleges and univer-

\begin{tabular}{lrccc}
\hline NERC staff reductions (from annual report) \\
HQ & $1980-81$ & $1981-82$ & $1982-83$ & $1983-84$ \\
NSS* & 191 & 191 & 191 & 186 \\
Institutes & 200 & 208 & 190 & 203 \\
\multicolumn{4}{c}{} \\
Staff levels (1983-84) as percentage of $1980-81$ \\
\% of \\
HQ & 2,870 & 2,750 & 2,678 & 2,376 \\
NSS & $1980-81$ & $\%$ & Change since & $1980-81$ \\
Institutes & 97 & & -2.6 \\
NEx & 101 & & +1.5 \\
\end{tabular}

*Excluding ships' crews.

sities in the United States, Canada and New Zealand where I took a similar interest in studies of equivalent organizations. I have found the work of the NERC institutes with which I am familiar to be generally of as high, if not higher, calibre as that in other countries. I was therefore surprised to learn of their present financial predicament. This led me to examine the NERC annual reports which contain the research council's record of diminishing manning levels between 1980 and 1984 (see table). The institutes (plus the British Antarctic Survey, BAS) have suffered a 17.2 per cent drop in manning levels against a 2.6 per cent drop in headquarters (HQ) staff and an actual increase in the NERC Scientific Services (NSS) of 1.5 per cent.

HQ and NSS contribute no commission- ed revenue towards the NERC budget whereas the institutes (not including BAS) do offset some of their costs through commissions. As it is also true that NSS is largely administrative in composition, this seems to be a rather good example of the tail wagging the dog. Surely cutbacks should be at least as heavy in the administrative sector (if not greater) as at the business end of the organization? That is certainly a difference between the way things are here in the United Kingdom and in the other countries I have mentioned.

It seems very sad, in light of this, that 1,000 scientific jobs are to disappear when, as seems probable, there should be some slack in administrative staff numbers yet to be taken up.

J.S. MCPHERSON

27 Louviers Road,

Littlemoor, Weymouth, Dorset, UK

\section{Value-free science}

SIR - Your correspondent M. Diesendorf (Nature 10 January, p.92 and 25 April, p.666) writes as if he believes complexity to be an adequate substitute for validity. If he does so believe he is in plentiful company, but errs nevertheless. Of course $\mathrm{LD}_{50} \mathrm{~S}$ are statistical statements; of course it is sometimes hard to isolate the cause of a particular death; of course juries are sometimes flummoxed. So what? Are "values" supposed to creep in under a sort of smokescreen?

As for the suggestion that the statement "I am going to poison my wife" may be "value-free" because it declares intent, let us recall the wise saying that there are times when one good laugh is worth ten thousand arguments.

M. HAMMERTON

University of Newcastle upon Tyne,

Department of Psychology,

Ridley Building, Claremont Place, Newcastle upon Tyne NEI 7RU, UK

\section{Mass extinctions}

SIR - R.C. Hope (Nature 18 April, p.574) complains that he has had enough of the wild speculations of recent years about the extinction of the dinosaurs. As a palaeontologist, I heartily agree.

However, Mr Hope thinks that it is the palaeontologists who are to blame. If he examines the credentials of the speculators, he will find that the great majority of them are not palaeontologists. In offering his own speculation (that the mammals destroyed all of the vegetation and ate the eggs of the dinosaurs faster than they could lay them), he falls into the class of people whom he wishes to criticize. No palaeontologist would subscribe to such a simplistic and biologically unrealistic notion.

M.J. BENTON

Department of Geology,

Queen's University of Belfast,

Belfast BT7 INN,

Northern Ireland, UK 